\title{
TRANSNATIONAL EXPERTISE AND EXPERIENCE NETWORKS AND RUSSIA'S ENVIRONMENTAL POLICIES
}

\author{
ANNE CROWLEY-VIGNEAU \\ ANDREY BAYKOV \\ MGIMO University, Moscow, 119454, Russian Federation
}

\begin{abstract}
This article offers an analysis of why Russia has been struggling to implement the environmental policies adopted by the government. While Transnational Advocacy Networks (TANs), much discussed in the Constructivist scholarship and concerned with forces behind normative and behavioral change, do indeed have an independent effect on the adoption of environmental laws, they act predominantly through intergovernmental channels, not necessarily impacting on society itself. This partly explains why norms get adopted but may end up not getting implemented. Based on the existing literature on TANs, the authors' inquiry establishes the fact that, to be successful in facilitating implementation, transnational networks can operate not only in the capacity of Advocacy Networks for the adoption of norms, but also as what the authors of this article previously chose to refer to as Expertise and Experience Networks, primarily aiming to aid norm implementation. Countries can be affected by TANs but not by TEENs, which might account for the paradoxical situation in Russia regarding norm implementation. The difference between the two only becomes apparent in cases when they do not operate simultaneously.
\end{abstract}

\section{Keywords:}

Transnational Advocacy Networks; Transnational Expertise and Experience Networks; Russian environmental policies.

Since the early 1990s, Russia has adopted a plethora of norms for the preservation of the environment; taken together, these constitute a robust legal framework similar to that of most countries of the EU. Russia is party to the majority of international agreements regarding environmental protection. Nevertheless, the Russian population's awareness of environmental issues remains limited, and the government faces uphill challenges in implementing the elaborate environmental legislation it adopted. The literature on norms implies that if a norm is "salient" [Cortell, Davis 2000] in other words, if it has reached the third stage of its life cycle [Finnemore, Sikkink 1998] and if, thereafter, it is translated in the law - there should be no real predicament regarding its proper implementation [Risse, Sikkink 1999]. However, our study of the situation in Russia demonstrates that environmental laws, even when "salient" and adopted under the influence of Transnational Advocacy Networks [Keck, Sikkink 1999], can be a real struggle to implement.

Дата поступления рукописи в редакцию: 20.08.2020

Дата принятия к публикации: 14.10.2020

Для связи с авторами / Corresponding author:

Email: acrowleyvigneau@yahoo.fr

baykovaa@yandex.ru 
In line with the existing literature on norms, Transnational Advocacy Networks play a significant role in raising the awareness about norms in the population of a given country. They do so through a variety of mechanisms, both transnational and intergovernmental. If TANs have an influence on the adoption of norms via an intergovernmental format, then society may be unaffected by this influence and the norm in question may not become domestically salient. The Russian case reveals that, typically, little to no attention is paid to the role of Transnational Advocacy Networks after national laws have been adopted. Being "Advocacy Networks", their role may be regarded as "fulfilled" once a norm has taken the shape of a legal rule and the responsibility for its implementation has been passed on to the national government [Betts, Orchard 2014]. However, what we have observed throughout the case study is a genuine struggle to implement norms in situations where norms are not domestically salient; there is also the obvious need for transnational networks, although not in their "advocacy" role but, rather, as facilitators influencing public opinion and aiding in the adaptation of international norms to national conditions. This struggle to domestically reach compliance with international norms, which have been institutionalized, has largely been neglected by the existing International Relations literature [Crowley-Vigneau 2020].

When highlighting the role TANs perform in norm implementation rather than norm adoption and their impact on social awareness within a country, the authors will refer to them as Transnational Expertise and Experience Networks (TEENs), which better qualifies the way networks help to organize and frame environmental issues. TEENs are networks that by providing technical expertise and sharing international experience, help norms to locally reach compliance [Vigneau, Baykov 2018]. Hence, in different situations and to emphasize the different functions of international actors, this article will employ the acronym TANs to denote pressure on states for norm institutionalization, and, accordingly, the acronym TEENs to denote pressure exertion and expertise diffusion at all societal levels for norm implementation.
The authors of the present article set out to explore the parameters which impact upon the efficiency of norm implementation and to expose some of the structural, institutional, and sociological causes for the difficulties encountered in the process. It is not the authors' intent to present an exhaustive view of environmental issues nor of Russia's situation, but, rather, through this individual case study, to gauge the role of international interaction in the implementation of environmental norms. The authors use the term "norm" according to Finnemore and Sikkink's definition as "a standard of appropriate behavior for actors with a given identity" (1998) and likewise consider "institution" to be a collection of norms on a particular topic [Finnemore, Sikkink 1998]. When the authors refer to the "government" they imply the authorities of a country. The terms "adoption" and "institutionalization" are used to designate a norm officially entering the legal system in a country, whereas the terms "implementation" and "enforcement" are preferred to describe the attempts to reach compliance with a legal norm. Because of the format of this study, the authors will refer to the influence of TANs and TEENs as a whole, and will not go into detail about the various actors comprising their make-up in each particular case. This article will first consider the reasons why environmental policies have sometimes failed to be implemented in Russia, then will examine the reasons for public unawareness of environmental problems, before defining the role TEENs could play in ensuring environmental norms reach compliance.

\section{1}

There are many reasons why environmental legislation has not been fully implemented in Russia; while these are not the focus of the current study, we will review some of the most crucial amongst them in brief before explaining why we consider social awareness (or, indeed, the lack of it) to be the key parameter in the equation.

The first reason has to do with the inertia of social institutions. Social stability persists and self-sustains, in spite of tendencies to change 
as ubiquitously found at micro- and macrolevels. Hence, even if a country is pressured to institutionalize a norm because all other countries have done so, one cannot simply assume that this norm will be implemented as a linear outcome of this outside pressure. Change entails effort; the status quo is far easier to maintain. Indeed, among the legislation adopted by governments, there are often laws or dispositions within laws which have been symbolic from the start, a by- product of international mimicry and a tribute to universally recognized values. The intention to implement those norms was never there in the first place. At a maximum, one could conceptualise such norms as references to the ideal scheme of things every nation aspires to attain, but at its own pace and, clearly, in its own time. G. Doron and M. Harris, in describing this "purposeful avoidance" of implementation, note that "there are many policies or laws that no one tends to or can mobilize the resources to enforce" and cite the example of age limits on cigarette vending machines [Doron, Harris 2000]. Similarly, another reason for the lack of implementation could be perception: a law was adopted to test society's reaction, as well as for affected entities (like firms and other enterprises) to start to prepare for implementation and consider the appropriate accommodation measures to manage the negative affects of the rule being put in place; Thus to the unprepared eye, nothing seems to have changed, and yet the preparation process is underway. This is similar to what was dubbed "prospective intervention" [Janicke 2012], except that the author was considering the effect of a measure being simply announced; we instead extend this theory to the case when a norm has been formally adopted but not fully implemented.

Based on the structural theory, the willingness to implement a norm may well depend on a country's position in the structure of the international system. If a society or interest groups within it deem their security potentially compromised as a consequence of a given norm being adhered to, the government will most likely decide to deliberately bypass the implementation phase of the norm, even if it may have succumbed to the pressure to accede to it intergovernmentally [Slaughter 1997]. Political elites may also fear that keeping to an international norm might diminish the state's sovereignty [Cortell, Davis 2000], another powerful reason to avoid implementation. A strong country does not usually experience any undue concern about international norms, partly because it may have had a lot of influence on the clarification of its content to begin with, so may be more willing to enforce it than a weaker country which had less of a say at the time of its creation. For historical reasons and because of its position in the international hierarchy, Russia has come across as rather suspicious of external normative influence ${ }^{1}$, which, inter alia, may have left a footprint on its implementation track record of international environmental norms.

The second explanation is institutional and linked to the fact that Russia can be presented as a political regime, previously construed as a vertical democracy [Naisbitt 2014]. While "government" is a term habitually used to refer to something cohesive, in reality, especially in vertical democracies, much infighting goes on between various factions of the seemingly united party in power, reflecting the manifold "schools of thought" and intellectual strands within the ruling class, but hence in the society at large, as to the optimal pathway of national development. To exert more influence and stay on in power, each faction seeks to be consistent with the opinion of the majority of the population, using various polls and surveys to monitor public opinion and resort to the polling findings in support of its position. This desire to do what the people demand alongside the constant inter-department fighting can result in paralysis of action, and can serve as an institutional explanation for why norms end up not being enforced.

The third reason is that the environmental norms institutionalized in Russia have been imported in large part from abroad, mainly from western countries; they have not been

\footnotetext{
${ }^{1}$ As reflected by the law on "foreign agent" self-appellation for non-profit organizations of July 2012 for example.
} 
adjusted to local conditions, and may not have been adapted to the levels of social and economic development of the country as a whole or for some of its regions. Norms can be too strict, not progressive enough, and not sufficiently supported by enforcement authorities through a lack of supporting infrastructure or know-how. An essential factor is that when norms are borrowed from elsewhere, there is often no expertise in the receiving country regarding how to go about its proper implementation. An obvious example would be roundabouts: these have been widely imported into Russia with the intent of providing more smooth and accident-free traffic management, but the associated rules regarding how to enforce the norm effectively have not been transmitted alongside the principle; also, little thought went into the specificities of the Russian climate and the fact that in snowy conditions roundabouts increase the risk of skidding and accidents. The consequence is that the situation on the roads has very often become more chaotic than before. Environmental rules suffer similar setbacks.

The fourth reason is related to the problem of social awareness. It is the reason that appears to be the most relevant, particularly within the framework of the Constructivist approach to norm implementation [Weiner, Puetter 2009]. The adoption of environmental norms in Russia has been taking place at the government's initiative and with little involvement from social society, business, and other actors, thus leading to implementation difficulties. We will consider the nature of these enforcement problems and show how a lack of environmental awareness could be considered responsible for the setbacks the environmental legislation has been continuously suffering.

The title of the latest OECD project carried out in cooperation with Russia, "Environmental Policy and Regulation in Russia: the Implementation Challenge", remains relevant today, and the main stumbling blocks have not changed. While many relevant laws exist and the decentralization of responsibility for the environment should have led to better efficiency, there remains a lack of coherence within the legal framework and enforcement difficulties ${ }^{2}$. In pursuit of higher efficiency, environmental authorities in Russia have been reorganized countless times (in 1994, 1996, 2000, 2004) ${ }^{3}$ making it difficult for them to be consistent or ensure a good quality follow-up of issues.

In the economic sphere, these challenges are openly recognized by experts within the government who note that the "end of pipe approach" has failed and seek out the reasons why: strict norms coupled with low fines and an insufficient system of inspections has made it cheaper for businesses to adopt the "wait and pay" approach than to reform in order to meet the legal requirements [Korppoo et al. 2015].

Another reason is that businesses often perceive environmental policy as strictly declarative, so see the associated rules as just more formalities standing in the way of their core function: making profits. Corporations and their leaders have not internalized the idea that environmental protection can be instrumental in improving their productivity and do not perceive energy saving as economically lucrative. An environmentally friendly culture in corporations, on the other hand, leads to more efficient norm implementation.

The same holds true for the population at large: new environmental norms get brushed aside unless the population has been directly affected or informed about the environmental issue [Sapozhnikova 2005]. An analysis of waste and recycling in Moscow shows that the population has little incentive to sort its waste because the scale of the problem has only recently started to become apparent. The 2017 "garbage crisis" and the related protests marked a turning point; however, an estimated $88 \%$ of Moscow garbage still ends up in

\footnotetext{
${ }^{2}$ Bartholomy $M$. et al. 2020. Environmental law and practice in the Russian Federation: overview. Thomson Reuters Practical law. Available at: https://uk.practicallaw.thomsonreuters.com/w-013-5609 ?transitionType = Default\&contextData $=$ (sc.Default)\&firstPage = true (accessed: 07.11.2020) .

3 Josefson J.A. 2012. Legislative Overview at a Glance: Russian Environmental Regulations. King \& Spalding. Available at: http://www.kslaw.com/imageserver/KSPublic/library/publication/Russian Environmental.pdf (accessed: 07.11.2020).
} 
Reasons for non-implementation of adopted norms

\begin{tabular}{|l|l|l|l|l|}
\hline Reasons & \multicolumn{1}{|c|}{ Nature } & \multicolumn{1}{|c|}{ Variants } & \multicolumn{1}{|c|}{ Key Actors } & \multicolumn{1}{c|}{ Motivations } \\
\hline 1 & Strategic & Deliberate avoidance, permanent or strategic & $\begin{array}{l}\text { National government, } \\
\text { elites }\end{array}$ & Fear, calculation \\
\hline 2 & Structural & Political infighting & $\begin{array}{l}\text { Factions of national } \\
\text { government }\end{array}$ & Power, survival \\
\hline 3 & Mimetism & $\begin{array}{l}\text { Norms imported from abroad, either unadapted } \\
\text { to local context or transferred without the } \\
\text { "know-how" necessary for implementation }\end{array}$ & $\begin{array}{l}\text { TANs and national } \\
\text { government }\end{array}$ & $\begin{array}{l}\text { Need for acceptance, } \\
\text { belief in usefulness } \\
\text { of norm }\end{array}$ \\
\hline 4 & Social & $\begin{array}{l}\text { Society does not understand the point of a norm } \\
\text { or the importance of the problem it targets }\end{array}$ & $\begin{array}{l}\text { Population, } \\
\text { businesses, } \\
\text { social groups }\end{array}$ & Ignorance \\
\hline
\end{tabular}

landfills ${ }^{4}$. The first recycling and sorting projects launched in 2012 yielded few results as most Russians were unaware of the scheme and didn't understand the point of recycling. The general opinion that "Russia is vast and that rubbish is taken far away" has been applied by the Moscow authorities, which have started to move the city's waste to sites in the Russian regions ${ }^{5}$. The challenges of creating a complex recycling system have also led the government to prioritize other solutions such as burning waste ${ }^{6}$. This situation leads to a vicious circle: the people cannot recycle because there is no infrastructure; and there is no infrastructure because of the pre-conception that the population will not recycle using it. The result is that the government is not creating the infrastructure necessary for the implementation of the norms it itself signed up for.

There are two archetypical ways in which a person becomes aware of a problem: they either see its pernicious mechanism unfolding in action and feel its consequences, or they are told about it. In the case of the environment, except in extreme cases, the second way prevails. Awareness is also something that builds up progressively and the more frequently reliable sources communicate relevant infor- mation, the more likely the message will get through. Conversely, conflicting information sows the seeds of doubt, undermining the goal in mind.

The process whereby a population becomes sensitive to an issue, such as the environment, is a complex one and is often performed by a network of actors. The analysis of the Russian case shows that while there are internal sources of information regarding environmental protection, they are insufficient, often contradict one another, and are poorly framed. In this regard, the authors will look into the role of the government, the media and NGOs, and by doing so discover that there are few actors from international networks working on environmental awareness in Russia.

Owing to the fact that it has been primarily (if not exclusively) the state that has acted as the entrepreneur of environmental norms in Russia, the population and business were not sensitive to these issues, and the challenge of norm implementation thus emerged. The government took upon itself the task of "enlightening" the population to this effect, as reflected in the President's decree dated from the 30th April 2012 on "The Principles of State Policy in the area of Environment Development of the Russian Federation until 2030", detailing the measures such as ecological education

\footnotetext{
${ }^{4}$ Colas R. 2019 Drowning in waste, Russians fume over lack of recycling. Phys.org. Available at: https://phys.org/news/2019-06-russians-fume-lack-recycling.html (accessed: 07.11.2020).

${ }^{5}$ Solovoya E. 2018 Moscow is solving its waste problem by sending it to the Russian regions. OpenDemocracy. Available at: https://www.opendemocracy.net/en/odr/moscow-is-solving-its-wasteproblem-by-sending-it-to-regions/ (accessed: 07.11.2020).

${ }^{6}$ Colas R. 2019 Drowning in waste, Russians fume over lack of recycling. Phys.org. Available at: https://phys.org/news/2019-06-russians-fume-lack-recycling.html (accessed: 07.11.2020).
} 
in schools and increasing the availability of information regarding some companies' adverse impact on the environment ${ }^{7}$. This process of promoting public awareness is not ineffective, but in the case of Russia it amounts to too little and comes too late, given that there is already a gaping discrepancy between norm adoption and norm implementation.

Transnational Advocacy Networks are useful in norm implementation as they provide an essential channel of transfer of expertise and experience from a multitude of sources at the same time. Networks have a more cogent way of conveying information than states acting by themselves. Currently, Russia is open to few actors of this networking type.

While some may underscore the presence of prominent environmental NGOs (WWF, Greenpeace, Friends of the Baltic and the Russian Social Ecological Union) in Russia, their role in the process of contributing to environmental awareness is limited. Moreover, there has been a waning in the last decade in their activities. The law on "foreign agent" self-appellation for non-profit organizations that receive foreign funding and engage in "political activity" has had a de-stimulating effect on NGOs' proactive stance, with some of them ending up devoid of their principal sources of funding. For example, Environmental Watch on Sakhalin returned 159 thousand dollars from a foreign sponsor so as to avoid the status of foreign agent ${ }^{8}$. That said, Western academic literature on NGOs does corroborate the claim that at the end of the day it may be detrimental for local NGOs to receive money from abroad, as becoming reliant on foreign financing is a stumbling block for a country in developing its own home-grown civil society [Hudock 1999]. The old idea of "who pays the piper calls the tune" explains the government's genuine concerns regarding foreign financing.

The role of the media in raising public awareness about the environment is ambivalent. The leading federal channels continue to reproduce the clichés about global climate conspiracies about plots to deprive Russia of revenue from the sale of fossil fuels and NGOs working to sabotage the Russian economy9. However, there is no denying that acting under the cover of a NGO is a good posture for an organization trying to advance a political agen$\mathrm{da}$, and that it is entirely plausible that multiple abuses of status of this kind were committed in the 1990s under the disguise of helping along the fledgling civic society.

Additionally, when environmentalists take on radical positions they turn the population and the government against them. The case of the activist Yevgenia Chirikova is indicative in this regard: her claim that Russia needs to completely stop selling oil for the environmental situation to improve appears excessive at the least and is unlikely to appeal to the average Russian. The fact that her ideas are taken seriously and relayed by the West (for example, by the Foreign Policy magazine ${ }^{10}$ ) shows that criticizing Russia has in some instances is treated as a more important job by the West than having a even-handed assessment of the situation.

Alas, poor framing of environmental issues pushes public awareness about the environment several steps back. A need to deconstruct the current framing of the environment - positing the link between the environment, natural resources, and national security and wealth is omnipresent and disserves the purpose, both coming from Russian and foreign authors. Famous (or infamous) academic works like

\footnotetext{
${ }^{7}$ Russian Federation President's decree. Principles of State Policy in the area of environment development of the Russian Federation for the period up to 2030. April 30, 2012.

${ }^{8}$ Russian NGO Returns DiCaprio Grant After Labeled 'Foreign Agent'. The Express Tribune. 2015. September 23. Available at: http://tribune.com.pk/story/962127/russian-ngo-returns-dicaprio-grantafter-labelled-foreign-agent/ (accessed: 19.11.2020).

${ }^{9}$ Vesti Nedeli s Dmitriyem Kisilevim [Week news with Dmitry Kiselev]. 2015. 28 June. Available at: https://www.youtube.com/watch?v=jiUvUjcnUTO (accessed: 19.11.2020).

10 Lozovsky I. 2015. Russia's Foremost Environmental Activist, in Exile: "Oil Is at Fault for Everything". Foreign Policy. Available at: http://foreignpolicy.com/2015/04/24/russias foremost environmental activist_in_exile_oil_is_at_fault_for_everything_evgeniya_chirikova/ laccessed: 19.11.2020).
} 
"the Siberian Curse", which recommends that Russia shrink its Siberian Cities in order to return to prosperity [Hill, Gaddy 2003], appear counterproductive to anyone with an environmentalist agenda as they threaten the integrity of the country and its core interests. Scholars have already highlighted the risks for NGOs linked to the loss of their legitimacy, as a result of their overt or implied association with Western hegemony, and to the harmful effects on their activities on the multilevel governance of such cross-border issues as the environment [Risse 2007].

There are few nationwide campaigns regarding the protection of the environment, and those that have been rolled out are relatively recent. Hence, at this point it is hard to appraise their impact on people's attitudes. The campaign "Vse Ravno?"11 (Russ.: "Are you indifferent?" or "Do you Care?"), which was launched in 2010 with the support of the Russian Ministry for Healthcare, engages in a form of social education in an array of different domains: health, education, road safety and security, as well as environmental protection. It is highly indicative, in our opinion, that the latter remains the least covered of all topics selected, with only five campaigns launched on just four subjects (disposal of batteries, disposal of waste, saving energy, protection of woods) compared to ten on health (incl. seven on smoking). "Vse ravno" addresses specific subjects through concrete situations and then engages the public by each time asking them the question "Do you even care?". By targeting particular topics and representing situations people experience in their lives, these rather well crafted campaigns enjoy the advantage of communicating a straightforward message (If I hold my barbecue in the forest, I am responsible for a fire), thus getting people to feel personally involved and to perceive the need to modify their behaviour.

While they are positively perceived by the general public, these campaigns have the following drawbacks: they do not show the national and international impact of their issues, and limit each problem to one of its aspects (not showing the consequences of forest fires for people and animals, for example). This type of framing does not convincingly illustrate that problems like forest fires and waste management are in fact global environmental issues. The campaign on waste is focused on educating people not to drop litter on the ground; for example, the "Protyani ruku" ("Reach out") campaign shows someone picking up some litter. This billboard does not give the general public any insight into the colossal problems of waste in Russia and inadvertently leads to downsizing the problem. While international advertisement campaigns are designed to shock and get people involved in a general cause, Russian advertisements are designed to stop a targeted type of dangerous behavior. The former is more likely to lead to the formation of a responsible society, while the latter is designed to solve a specific problem. The type of advertisements made by NGOs are not as yet widely diffused in the Russian media; this is possibly because the style is perceived as too dramatic and not sufficiently specific. Russia has yet to elaborate its own authentic style of environmental campaigning, which can raise the general awareness of the population on the full scope of environmental problems the country has to reverse.

Public unawareness of environmental issues stems from the fact that the initiatives to sensitize the population are recent, uneven, and spearheaded mainly by the state. The main argument of this study is that governments can choose not to involve TEENs to increase social awareness for reasons of a higher order such as national security, but that they should be aware that by so doing they are complicating the process of norm implementation. Nevertheless, TEENs appear as powerful actors in increasing public awareness on environmental issues.

Transnational Advocacy Networks can lead to norm adoption by a national government through intergovernmental mechanisms, with

${ }^{11}$ Vse Ravno [Don't care] Campaign Website. Available at : http://vse-ravno.net/campaigns laccessed: 19.11.2020). 
the society of the target country remaining totally unaware of the process and having no contact at all with non-governmental actors. The Russian case and the implementation gap it reveals brings us to expand on the notion of TANs, which go beyond being advocacy networks to assuming an entirely new role as Transnational Expertise and Experience Networks. We argue that TEENs play the role of catalyst and facilitator in norm implementation by raising public awareness about the problems and the norms and by aiding in the adaptation of international norms to local conditions. Scholars have depicted how international institutions can contribute to giving voice to concern and exposing the implications of environmental problems [Haas et al. 1993], as well as the role NGOs can play during the national implementation of an international norm by offering monitoring and information gathering capacities and by putting pressure on the State by placing the implementation process of a norm in a country in the limelight [Risse 2007]. However, the role of TEENs takes on a new dimension as it does not focus on outside pressure and checking mechanisms, "catching the wrongdoers out", but, rather, assumes that the reasons for non-implementation are linked to an inability, sometimes carefully concealed, to do so. TEENs involve a multitude of different actors, which can actually help countries develop and implement their legislation.

The literature has identified a number of factors that render a norm successful in terms of domestic implementation such as a cultural match (norm resonates with domestics norms, beliefs, obligations), rhetoric by leaders supporting the new norm, a positive link between the norm and domestic interests, and strong domestic institutions [Cortell, Davis 2000]. While these criteria are mostly considered as a given, we argue that TEENs can have a direct impact on changing these actors and factors, as well as on improving the "political system's capacity for environmental policy" through modernization strategies [Janicke, Weidner 2012]. A network type of interaction may be the most efficient way to improve this capacity, addressing and framing environmental issues and norms so as to make them appealing to the Russian population or financially worthwhile for businesses.

TEENs are comprised of diverse actors: international churches, non-governmental organizations, lobbies, experts, universities, transnational corporations, the media, social movements, trade-unions, and parts of governments, but also of individuals who decide to network in favor of a cause. As described in the literature, TEENs play the role of catalyst and facilitator in norm implementation by raising public awareness about the problems the norms address and by aiding in the adaptation of international norms to local conditions [Vigneau, Baykov 2018]. TEENs can impact upon environmental awareness in Russia in several ways: by showing businesses that the price to pay for harming the environment is high and that being environmentally friendly offers a competitive edge in the international arena; by supplying information to the population and relating some success stories; by sharing the international experience of efficient framing; and by providing the Government with expertise, emphasizing the economic benefits of recycling and acting as a constant reminder of the salience of environmental issues.

\section{Impact on Business}

TEENs can play an important part in helping along norm implementation through more decisive actions in the corporate sector. For Russian companies, to stop playing cat and mouse with the Russian environmental compliance authorities, they should be made aware of the advantages for businesses of adhering to these norms and reforming their system of production accordingly. TEENs have many ways of putting this information across to companies and showing them that complying with environmental regulation, as well as anticipating it, serves their economic and reputational interests. Multinational corporations can set an example for other firms and share not only their success stories but also the technical solutions they found for each challenge. The corporation Zara operates a clothing recycling program in Russia, using its experience of do- 
ing so abroad 12 , "second-hand" shops are appearing on the streets of Russia's main cities ${ }^{13}$. The attitude to environmental issues in firms can radically change under the influence of TEENs.

Encouraging firms to participate in voluntary types of environmental management systems is an efficient means of encouraging them to cut down on their emissions. Szymanski and Tiwari [Szymanski, Tiwari 2004], in their study of 264 manufacturing facilities in the US that had obtained ISO 14001 certification from 1996 to 2001, discovered that $75 \%$ of them "experienced a reduction in their emissions". Such participation in voluntary programs provides "non-rival but potentially excludable benefits to members" who are willing to spend more on taking environmental action, as they reap "reputational benefits" that you do not otherwise obtain if you act unilaterally [Potoski, Prakash 2005].

Furthermore, interest in ISO standards is growing internationally, and some countries such as the UK, the Netherlands and South Africa - have already announced they would favor ISO 14001 certified companies in procurement contracts [Emetumah 2017]. Hence, not only do companies stand to save money by complying with environmental norms, but they also enjoy a better reputation on international markets. The Russian government, acting hand in hand with international business associations, could raise the awareness about ISO standards among companies and the general public. The promotion of such standards leads companies to fully enter the transnational network, interacting with international agencies and businesses, exchanging information and best practices and negotiating their presence on the international market.
Another way of integrating into TEENs and of encouraging firms to fulfill environmental norms is by "naming and shaming" guilty actors across the country. Non-governmental organizations carry out campaigns revealing which companies breach environmental standards. The NGO CorpWatch coined the term "greenwash" to qualify companies which are socially and environmentally destructive but which try to expand their markets by posing as friends of the environment ${ }^{14}$. These efforts gain in efficiency when they are relayed by the media, as in the case of the Guardian and its Greenwash column ${ }^{15}$. Sometimes pressure from outside is an effective technique to get companies to conform to national policies. As they include large multinational corporations, worldwide consumer networks, trade unions, and non-government associations, TEENS have the power to advise, influence and pressure firms, leading them indirectly to observe environmental norms adopted by the government of the country they operate in.

\section{Impact on population}

The effectiveness of international interaction also applies to the population at large. TEENs can draw people's interest to a specific topic and provide information. Many actors can be involved: organizations, universities, but also individuals who through social networks can defend causes they believe in.

Consumers may perceive it as their duty to get involved in monitoring the activities of local businesses. In the "Green State" Eckersley remarks that "All those potentially affected by ecological risks ought to have some meaningful opportunity to participate or be represented in the determination of policies or decisions that may generate risks" [Eckersley 2004]. Indeed,

\footnotetext{
${ }^{12}$ Clothes collection 2020. Zara. Available at: https://www.zara.com/ru/en/sustainability-collectionprogram-mkt1452.html (accessed: 11.11.2020).

13 Davies K.M. 2019. Can a new range of charity shops break Russia's second-hand stigma? The Calvert Journal. Available at: https://www.calvertjournal.com/articles/show/11147/sustainability-russiaretail-charity-shops-busting-second-hand-stigma (accessed: 11.11.2020).

${ }^{14}$ Acaroglu L. 2019. What is greenwashing? How to spot it and to stop it. Disruptive Design. Available at: https://medium.com/disruptive-design/what-is-greenwashing-how-to-spot-it-and-stop-it-c44f3d130d5 (accessed: 11.11.2020).

${ }^{15}$ Greenwash. The Guardian. 2020. 15 April. Available at: https://www.theguardian.com/environment/ series/greenwash (accessed: 11.11.2020).
} 
when consumers realize that there is a reliable way of assessing the impact a company has on the environment, they begin to favor those companies that make an effort to be "green". TEENs can enhance a population's sensitivity to environmental issues and contribute to correctly "framing" a given problem, presenting it in the right way "to fit a venue and to resonate with a broader public" [Keck, Sikkink 1998].

Environmental challenges are complicated to convey to the general public as there is always more than a hint of uncertainty regarding what may be impactful within a certain timescale. Going into scientific technicalities, presenting fickle expert assessments, and touching on a multitude of issues at once increases the risk of confusion. International NGOs have experience in "turning cold facts into human stories" [Keck, Sikkink 1998] and appealing to people's interests. Informing the population what they may save by cutting back on their energy consumption is a strategy which could work well in combination with an emotionally moving representation of the general good for the environment resulting from a small effort.

In a vast country like Russia, endowed with abundant resources, the population is routinely led to think that something so seemingly small, such as properly disposing of one's batteries, is bound to have virtually no impact whatsoever on anyone's or anything's wellbeing. A proper framing of the issue could alter such perceptions. Meanwhile, to perform effectively when interacting with or through TEENs, NGOs and their activities should not be framed as perilous to a country's sovereignty. It is noteworthy in this regard that, precisely with this in mind, some of the most effective NGO campaigns posed themselves as defending national interests. A telling example is Greenpeace's campaign against the export of
French Nuclear waste by $A R E V A$ to Russia ${ }^{16}$. Behavioral changes as a result of interaction with TEENs lead to a greater willingness amongst the population to respect environmental norms [Tarrow 2005]. For example, this means that when the government chooses to start sorting and recycling waste, the population will be ready to comply.

\section{Impact on Government}

As concerns the government authorities, going beyond intergovernmental relations and starting to interact with other actors making up TEENs presents a number of advantages, such as obtaining more accurate and comprehensive information, practical support, and help in adapting norms to the local conditions. TEENs could aid in implementing recycling in Russia by disseminating information regarding the state of dumps located near towns, by explaining the associated health hazards, by sharing the experience of countries which have overcome this kind of challenge, by helping to design infrastructure suited to Russian conditions, by sharing the system of financial initiatives with the authorities as elaborated in other countries etc. TEENs can provide expert assessments of the economic benefits of recycling in a specific country, region or town, hence giving the population and the authorities an incentive to change their ways. According to one estimation, Russia could yearly save 60 billion rubles alone were it to fully recycle its hard household waste (against the 15\% currently recycled $)^{17}$. Statistics regarding air pollution help to comprehend the health and economic toll of this phenomenon, with experts assessing the number of fatalities it causes in Russia at 100 thousand a year and the economic cost at $8,3 \%$ of the Russian Gross National Product ${ }^{18}$.

TEENs bring in diverse actors that share a myriad of different experiences and make it

\footnotetext{
${ }^{16}$ Public Pressure Stops French Nuclear Waste Export to Russia. Greenpeace International. Available at: http://www.greenpeace.org/international/en/news/features/Public-pressure-stops-French-nuclearwaste-export-to-Russia/ (accessed: 29.05.2010).

17 Solving the problem of municipal solid waste management in Russia. 2018. Available at: http:// meridiandobra.ru/wp-content/uploads/2018/11/recycling-in-russia-eng.pdf (accessed: 11.11.2020).

18 Average number of deaths attributable to air pollution in Russia from 1990 to 2017*. Statista. 2017. Available at: https://www.statista.com/statistics/827771/air-pollution-deaths-russia/ (accessed: 11.11.2020).
} 
possible to adapt international norms to a local context. They do not act by putting pressure on the government but, rather, by helping it to frame issues and raise awareness about a problem among the population and corporations.

The case study of Russian environmental law reveals that there are situations in which transnational networks influence national governments and lead to the adoption of new laws, without society being aware of or ready for these new norms. This study shows that the involvement of transnational networks at the "advocacy stage" does not ensure their participation or help at the implementation stage. We identify this as one of the reasons why norms adopted by national governments with international support occasionally fail to reach compliance. This study also reveals the multiplicity of roles performed by transnational actors, going well beyond advocating a cause, and the need for their intervention as Transnational Expertise and Experience Networks, raising awareness among the population and helping national governments with implementation. One of the key problems today is that, due to the difficulties in implementing norms and the lack of appreciation of the potential benefits of environmental protection, companies, the population at large, and even the authorities themselves have started to seriously question whether there is much point in implementing the existing norms to their spirit and letter. While political speeches on environmental topics still flourish, the interest in the relevant norms as well as their implementation runs the risk of gradually dissipating into the void, and their salience is being increasingly, albeit covertly, contested.

\section{References}

Betts A., Orchard P. (Eds.). (2014). Implementation and world politics: how international norms change practice. OUP Oxford.

Crowley-Vigneau A. (2020). Norm Implementation: the Achilles' Heel of Constructivist Theory?. Vestnik MGIMO-Universiteta. Vol. 13. No. 4. P. 199-215. https://doi.org/10.24833/2071-8160-2020-473-199-215

Doron G., Harris M. (2000). Public Policy and Electoral Reform: The Case of Israel. Md.: Lexington Books. 127 p.

Eckersley R. (2004). The Green State. Rethinking Democracy and Sovereignty. Cambridge, MA: MIT Press. $331 \mathrm{p}$.

Emetumah F. C. (2017). Integrated management systems as a risk management tool: Combining ISO 9001, ISO 14001 \& OHSAS 18001 standards in process industries. Risk, Reliability and Safety: Innovating Theory and Practice, 1216-1221.

Finnemore M., Sikkink K. (1998). International Norm Dynamics and Political Change, International Organization. Vol. 52. No. 4. P. 887-917.

Haas P., Keohane R., Levy M. (eds) (1993). Institutions for the Earth: Sources of International Environmental Protection. Cambridge: MIT. 448 p.

Hill F., \& Gaddy C.G. (2003). The Siberian curse: How communist planners left Russia out in the cold. Brookings Institution Press.

Hudock A. (1999). NGOs and Civil Society: Democracy by Proxy? Polity. 120 p.

Keck M., Sikkink K. (1999). Activists Beyond Borders: Advocacy Networks in International Politics. Ithaca: Cornel University Press. 228 p.

Korppoo A., Tynkkynen N., Hønneland G. (2015). Russia and the politics of international environmental regimes: Environmental encounters or foreign policy? Cheltenham: Edward Elgar Publishing. 161 p.

Naisbitt J. (2014). Vertikal'naya demokratiya v Kitae [Vertical democracy in China]. Mezhdunarodnye protsessy. Vol. 7. No. 3. P. 45-46.

Risse T. (2007). Transnational Actors and World Politics. In: Zimmerli W. C., Richter K., Holzinger M. (eds) Corporate Ethics and Corporate Governance. Springer Berlin Heidelberg. P. 251-286.

Risse T., Sikkink K. (1999). The Power of Human Rights: International Norms \& Domestic Change. Cambridge.

Sapozhnikova V. (2005). Environmental Protection in Russia: The Evolution from Strict Enforcement Measures and Environmental Compliance Control to New Combined Approaches Based upon Preventive Strategies. Proceedings of the Seventh International Conference and Enforcement, INECE, 7th Conference. Washington DC, pp. 183-188.

Slaughter A.M. (1997). The Real New World Order. Foreign Affairs: New York. 
Szymanski M., Tiwari P. (2004). ISO 14001 and the Reduction of Toxic Emissions. The Journal of Policy Reform. 7(1): 31-42.

Tarrow S (2005) The New Transnational Activism. Cambridge University Press.

Vigneau A., Baykov A. (2018). Pochemu gosudarstva zaimstvuyut ekologicheskie normy: opyt Rossii [Transnational Networks and Russia's Environmental Policies]. Mezhdunarodnye protsessy. Vol. 16. No. 4. P. 137-153.

Weiner A., Puetter U. (2009). The Quality of Norms is what Actors Make of It: Critical Constructivist Research on Norms, Journal of International Law and International Relations. 5(1): 1-16.

Russian Federation President's decree (2012). Principles of State Policy in the area of environment development of the Russian Federation for the period up to 2030. April 30.

\title{
ТРАНСНАЦИОНАЛЬНЫЕ ЭКСПЕРТНО- \\ ПРОФЕССИОНАЛЬНЫЕ СЕТИ И ПРИРОДООХРАННАЯ ПОЛИТИКА РОССИИ
}

\author{
АНН ВИНЬО \\ АНДРЕЙ БАЙКОВ \\ МГИМО-Университет, Москва, 119454, Российская Федерация
}

\section{Резюме}

В статье излагаются результаты исследования, конечная цель которого состояла в том, чтобы объяснить, почему Россия испытывает трудности с соблюдением природоохранных норм, уже закреплённых на уровне законодательства. Трансграничные общественные движения в защиту тех или иных претендующих на универсальную применимость и глобальное значение стандартов поведения, функционирующие по сетевому принципу организации и часто обозначаемые в специализированной литературе термином «транснациональные сети убеждения» (transnational advocacy networks, TANs), действительно играют важную роль в развёртывании жизненного цикла норм, ускоряя процесс её осознания на международном уровне и способствуя её принятию в национальных рамках. Вместе с тем, поскольку эти сети действуют преимущественно в глобальном срезе мирополитической системы, их влияние практически не заметно внутри отдельных политий, на уровне их общественного сознания. Это отчасти объясняет то, почему нормы принимаются, но могут оставаться полностью или частично нереализованными.

Начиная с 1990-х годов Россия имплементировала в свою законодательную систему обширный корпус норм и стандартов, регулирующих различные аспекты защиты окружающей среды. В совокупности они образуют довольно разработанную и зрелую отрасль внутреннего права, во многом сравнимую по степени своей детализации и охвату с лучшими мировыми практиками. Сегодня Россия - участник большинства международных соглашений природоохранного профиля. Вместе с тем осведомлённость населения России о реальном состоянии экологических проблем в стране, адекватное осознание им масштаба и важности практических усилий по их ослаблению и разрешению по-прежнему остаются весьма незначительными, что в немалой степени снижает эффективность правительственных мер по реализации принятых на себя обязательств в экологической сфере.

В рамках сложившегося научного дискурса по проблематике эволюции норм утвердилась концепция, согласно которой если норма становится «значимой» (salient), или иначе - достигает третьей 
фазы своего жизненного цикла, то после того, как она принимается в национальных рамках и обретает силу закона, на пути её практического внедрения не должно возникать никаких существенных препятствий.

Между тем наш анализ ситуации в России показывает, что экологические нормы, даже «значимые» и принятые под влиянием так называемых транснациональных сетей убеждения (Transnational Advocacy Networks, далеe - TANs), сталкиваются с серьёзными проблемами на стадии реализации (внедрения и соблюдения). В согласии с утвердившимся в специализированной литературе пониманием TANs играют важную роль в повышении уровня осведомлённости о важности тех или иных норм и добиваются этого с помощью различных механизмов, как транснациональных, так и межправительственных. В то же время деятельность TANs, осуществляемая в межправительственном формате, как правило, никак (или весьма несущественно) не затрагивает само общество. Как следствие, международная неоспариваемая норма может носить далеко не безусловный характер внутри страны, то есть не приобрести статуса «значимой» - в терминах соответствующего научного дискурса.

Изучение российского опыта свидетельствует, что после того, как та или иная международная норма имплементируется в национальное законодательство, дальнейшая роль TANs в процессе практического внедрения норм и её последующего соблюдения по существу остаётся за кадром исследовательского фокуса. Последнее в известном смысле объяснимо, поскольку роль TANs можно считать выполненной после того, как норма облечена в законодательную форму, а ответственность за её соблюдение передана национальному правительству. В то же время не редки случаи, когда в силу того, что та или иная норма не воспринимается как «значимая» населением страны, наблюдается стагнация уже законодательно оформленных норм.

В статье предпринята попытка исследовать параметры, которые влияют на эффективность реализации нормы, а также выделить некоторые структурные, институциональные и социологические причины трудностей в реализации нормы. Целью данной статьи не является представление исчерпывающих сведений о проблемах окружающей среды или специфический обзор конкретно российской ситуации.

Исходная гипотеза настоящего исследования состоит в том, что для повышения эффективности соблюдения норм транснациональные сети должны перейти из «режима пропаганды» принятия норм в режим «опосредования» и трансляции экспертно-практического знания, или компетенций, необходимых для адаптации нормы к местным условиям для её эффективного внедрения. В последнем случае авторы будут обозначать такие сети как транснациональные экспертно-профессиональные сети (transnational expertise and experience networks). Их главное предназначение заключается в том, каким образом адекватно дискурсивно оформить (frame) экологические проблемы, с тем чтобы повысить ранг их значимости в глазах населения. Эвристически различие между ними становится очевидным и аналитически существенным только в тех случаях, когда они не функционируют одновременно.

\section{Ключевье слова:}

транснациональные сети убеждения; транснациональные профессионально-экспертные сети; экологическая политика в России. 